\title{
DIMENSIONING OF WALKWAY IN REINFORCED CONCRETE
}

\author{
Bruno Felipe Castro da Silva ${ }^{1}$, Jusiclei Moraes ${ }^{2}$, Raimundo Ocimar Ferreira Macena ${ }^{3}$, Jorge de \\ Almeida Brito Junior ${ }^{4}$, David Barbosa de Alencar ${ }^{5}$ and Camily Murrieta Vasconcelos Oliveira \\ Bezerra $^{6}$
}

\author{
1, 2, 3, 4,5 Blauro Cardoso de Mattos Higher Education Institute - FASERRA. Manaus-Amazonas, Brazil. \\ ${ }^{6}$ Nilton Lins University. Manaus-Amazonas, Brazil.
}

Email: brunocastroo@live.com, jorgebritojr@gmail.com, david002870@hotmail.com, camilymv@hotmail.com

Received: Aug 19th 2019

Accepted: Aug 30th, 2019

Published: December 02 ${ }^{\text {th }}, 2019$

Copyright (C2016 by authors and Galileo Institute of Technology and Education of the Amazon (ITEGAM).

This work is licensed under the Creative Commons Attribution International License (CC BY 4.0).

https://creativecommons.org/licen ses/by/4.0/

Open Actese

\begin{abstract}
Walkways are scaffolding erected to cross natural or artificial barriers and take care of the passenger's own safety. There are walkways over rivers, lakes, roads, railroads, valleys and also as connections between buildings, which aim at the physical distance between pedestrian flow and disorders that individuals are not able to cope with, such as water currents, the height of buildings and vehicles at high speed. The theme "Design of Reinforced Catwalk" aims to demonstrate how the design of a reinforced concrete walkway, showing the possible pathologies that may occur in these structures. The article followed the precepts of exploratory study, through bibliographic research, was developed from material already prepared, consisting of scientific articles. It has been found that it is important to consider the permanent load of the element. In the case of walkways, the load must be established in addition to its own weight, by variables that are part of the physical framework itself, other fixed overloads, such as: concrete slab, steel structures, paving, railing, signs, among others. . As for pathologies, it was concluded that the best option to prevent pathological conditions is prevention. Prevention is generated not only by a project or execution within the quality parameters, but mainly by a structural maintenance program. These programs play an important role in any structure, facilitating the verification of structural deterioration states and favoring the reduction of treatment costs. These procedures will certainly prevent the formation of marked and widespread pathologies.
\end{abstract}

Keywords: Reinforced Concrete, Walkway, Scaling, Pathologies.

\section{INTRODUTION}

A walkway can significantly decrease the number of runover accidents in a given neighboring area. However, in order to fulfill its function, the structure must be in good working order, with an effective conservation, and it must also have a design that attracts the user's attention, that is, to make the user confident and safe in its crossing [1].

When the basic design is elaborated, it is important to analyze the structural systems of preambular research so that the design of the work is exquisitely combined with the site and various surrounding buildings, where appropriate. For this phase, it serves as a database a planialtimetric survey, surveys, geometric design of the crossing, number of passers-by at peak time etc.
Pedestrian flow is greatly reduced if a walkway is erected in an improper location due to lack of planning. Therefore, a good research or case study is important for walkway design, a strategically appropriate deployment site, top quality materials for both architectural design optimization and optimum structural design that allows for simplified maintenance [1].

The theme "Design of Reinforced Concrete Walkways" is fully justified as the construction of a walkway brings great benefits to the traffic, which reduces the time of crossing, favors drivers, who will also reduce the travel time by not having to stop at the signs.

The work followed the precepts of the exploratory study, through bibliographic research, which, according to [2] is developed from material already prepared, consisting of scientific 
articles. In the selection of articles, the following steps were followed: evaluation of titles, evaluation of abstracts and reading of the full text.

The theme has the main objective of demonstrating how the design of a reinforced concrete walkway is presented, presenting the possible pathologies that may occur in these structures.

\section{LITERATURE REVIEW}

\section{II.1 CATWALKS}

Walkways are definitive frameworks that, in addition to providing a cross between two points, can positively cooperate with the environment in which they are planted or mint an emblem for the region, a fact that must be taken into account when designing the project [3].

According to the Brazilian Traffic Code, the footbridge is the proposed work of art for pedestrian crossing. As [4] is a work for accessibility to buildings, furniture, spaces and urban equipment.

According to [5] footbridge is a long frame, for crossing natural and / or artificial barriers only for pedestrians and / or cyclists.

[6] ensures that the walkway allows crossing and secures a crossing with complete safety. Pedestrian walkways, according to [4], need to be provided with ramps, ramps and ladders, ramps and elevators or ladders and elevators for their transposition, and the ramps, stairs and elevators comply with this same norm.

Footbridges, or pedestrian bridges, are specific works of art temporarily or permanently built, proposed to overcome natural and / or artificial obstacles. In archaic times such transposition tools were architected in rope and wood, in the form of beams, braced beams, and simple reinforced beams. Civilization brought with its stone bridges even before the Christian period. Around the beginning of the 19th century, arched cast-iron bridges appeared, followed by wrought iron and steel materials, giving rise to the first large beam bridge with wrought iron cellular section [7].

The walkways can be evaluated and qualified mainly by four variables: Type of access, type of board, type of fences and type of structural system used.

According to [8] the access can be made in three level situations: two ends in the same planes of the pedestrians; only one end on the same level as the pedestrian walk; two ends at unequal heights of pedestrian walkways.

As for the board, [9] states that "a platform or bridge board is the part that immediately supports the road function elements, such as railways, tracks, sidewalks, ducts, etc.".

The function of the board is to directly assess the loads passing through the bridge. Structural systems are stipulators of the most important qualities of catwalks, they can determine their shape and plastic expression and give specifications or conditions concerning spans, supports, accesses, jigs and assembly processes [10].

The various types of catwalks can be categorized by the material used, the size of its span or the structural system employed. One of the most widely used structural systems is that of beams, which operate essentially with shear forces and bending moment [9].

For [8] the structural conformation of the beams is of the simplest, fundamentally constituted by only one element supported or embedded in columns or bases in the ground. The beam system is the most effective and cheap for small spans (10 to 25 meters), with low production, painting and maintenance costs, as well as ease of installation, requiring the use of light equipment and little intervention in local traffic.

\section{II.2.2 ARMED CONCRETE}

Concrete is conceptualized as an artificial rock created or developed from the combination and subsequent hardening of a binder (cement), water, fine aggregate (quartz sand), coarse aggregate (gravel), with or without chemical additives [11].

According to [12], the concrete execution steps are: characterization of the concrete component materials and according to NBR 12654; concrete dosage study; adjustment and verification of the concrete trace; concrete preparation.

The term "structural concrete" is one that alludes to the full spectrum of all concrete applications as a material used in structures.

\section{RESEARCH METHODOLOGY}

This work was developed from the research of the development concepts of the catwalk project, the concrete concepts were raised, from this concept, the elements such as catwalk design, dimensioning and the main pathologies were developed.

\section{STUDY APPLICATION}

In this item will be presented the main elements of the development of a catwalk project, will be demonstrated from bibliographical references.

\section{IV.1 DESIGN OF A CATWALK}

For the design of a footbridge design, the points listed in the National Department of Transportation Infrastructure (DNIT) Rail Services Instruction No. 219 may be exceeded and considered for a variety of footbridge species and are not restricted to of railway crossing.

According to [13], the catwalk design must appreciate ways to deviate from its misuse. According to [14], some elementary directives allow catwalk designs a great aesthetic target. Such as, for example, the choice of appropriate geometry for the catwalk cross sections; option for light railing; opting for details that maintain the cleanliness and strength of the work.

Pedestrians may be encouraged to use catwalks by implanting flower boxes, railings, chains or other devices, which are seated to guide individuals to the catwalk, offering a little more charm or liveliness to this element. Pedestrians may be compelled to use walkways for physical hindrances that prevent the crossing of the runway, such as tall concrete walls and wire enclosures [1].

Positioning a catwalk is of vital value given that there is a certain aversion on the part of people to use them. According to the National Department of Roads [14]:

The generally undisciplined user should be practically compelled to use the catwalk; To do this, access ramps must begin and end at points of natural attraction such as street intersections, factory exits, schools, etc.

[...] Without a blocked road, without a heavy traffic, without favorable topographic conditions and without the existence of well-defined points of attraction, the walkway will be little used and will only serve to stifle the public clamor that arises when run over.

The place to be built a walkway may also influence the choice of the construction method followed, as it may not be 
appropriate to temporarily interrupt one or more lanes in the street for the proper support or shoring of the work.

The Special Works Design Manual of the now defunct National Roads Department of 1996 provides some basic precepts that allow for aesthetically successful catwalk designs:

a) availability of areas for development of access ramps;

b) greide continuity throughout the work: central section and access ramps;

c) choice of a continuous structural system and, if possible, provided;

d) choice of suitable geometry for walkway, ramp and pillar cross sections;

e) choice of light railing;

f) choice of details that preserve the cleanliness and durability of the work;

g) The details chosen should be in proper proportion to the rest of the structure, emphasizing their lightness with artifices such as presentation of faces exposed on different planes, harnessing the favorable effects of natural shadows, etc.

Feedback is important as it will provide the minimum horizontal or vertical clearance required for vehicles to travel under the catwalk and continue to travel safely in the traffic lane. Thus, the measures of the template will define the sizes of the free spans of the work. The Urban Crossing Geometric Design Manual indicates in simplified tables the vertical and horizontal templates to be followed:

Table 1: Minimum Vertical Template.

\begin{tabular}{|c|c|}
\hline Roads & $\begin{array}{c}\text { Vertical template } \\
(\mathbf{m})\end{array}$ \\
\hline Expressways & 5,50 \\
Arteries that act as extensions of the & 5,50 \\
national road system & \\
Other arterial ways & 4,50 \\
\hline
\end{tabular}

Source: [15].

Table 2: Width of rolling tracks.

\begin{tabular}{|c|c|c|}
\hline \multirow{2}{*}{ Track Category } & \multicolumn{2}{|c|}{ Rolling Track Width (m) } \\
\cline { 2 - 3 } & Desirable & Minimum \\
\hline Expressways & 3,60 & 3,50 \\
Arteries * & 3,60 & 3,50 \\
Directive speed $60-80 \mathrm{~km} / \mathrm{h}$ & 3,50 & 3,30 \\
\hline Guideline speed $50-60 \mathrm{~km} / \mathrm{h}$ & \multicolumn{2}{|c|}{} \\
\hline $\begin{array}{c}\text { * Values exclusive width adjacent to curb, reserved for gutter, with a minimum } \\
\text { value of } 0.30 \mathrm{~m} .\end{array}$
\end{tabular}

Source: [15].

Table 3: Width of shoulder for expressways and some primary arterials.

\begin{tabular}{|c|c|c|}
\hline Number of lanes per direction & \multicolumn{2}{|c|}{$\begin{array}{c}\text { Minimum width of } \\
\text { shoulders (m) }\end{array}$} \\
\cline { 2 - 3 } & Internal & External \\
\hline 2 or 3 & $1,20(0,60)$ & $3,00^{*}(2,00)$ \\
\hline 4 or plus & $3,00(1,00)$ & $3,00^{*}(2,00)$ \\
\hline
\end{tabular}

* Preferably $3.50 \mathrm{~m}$, where an hourly volume of trucks is expected to exceed 250 vehicles.; ( ) minimum values under strict conditions.

\section{Source: [15].}

Regarding the cross section, to define the cross section of the catwalk superstructure board it is necessary to check the laws, rules or manuals of good practice alluding to this type of structure. As recommended [15] "Pedestrian paths should have a minimum width of $2.40 \mathrm{~m}$. Larger widths may be needed for exceptionally high pedestrian volumes, as they are in the central areas of large cities and around sports stadiums."

However, [16] recommends a slightly larger width, stating that "The latest DNER catwalk designs show a tendency to adopt a very satisfactory overall width of $2.50 \mathrm{~m}$."

Regarding the structural aspect of the option for the cross section, [7] points out some variables that interfere with decision making:

a) size of the gap referred to the structural system adopted;

b) available structural height or desired leanness, expressed as $\mathrm{l}: \mathrm{h}$ or $\mathrm{li}: \mathrm{h}$, in case of continuity, where li = approximate distance between points of zero momentum $(\mathrm{Mg})$;

c) construction process, available means, equipment, etc;

d) economics of the chosen construction process. Slender structures require a higher consumption of steel than less slender ones; On the other hand, the consequences on the ramps must be taken into account.

e) ratio q: g = moving load: eigen weight. Large values of $\mathrm{q}$ : $\mathrm{g}$ imply, in the case of prestressed concrete beams, additional amounts of concrete in the tensile flange, such as the adoption of double $\mathrm{T}$ or coffin sections.

The railings, on the other hand, are frames located on the side edges of the catwalk board with the purpose of securing the safety of the passerby. They can be formed by concrete, metal or mixed profiles and need to have elevation that varies between 90 and $100 \mathrm{~cm}$. A concrete railing has the conveniences of more security, lower cost, less time-consuming maintenance and is not at the mercy of theft. However, they are much denser compared to a metal railing, and when it is not architectural art, they often suffer from a lack of aesthetics [16].

\section{IV.2 SIZES OF CATS}

Usually the walkways we find most on the highways of Brazil, are the concrete walkways, commonly prefabricated, have no roofs, and the method of resolving the gap is through ramps. There are other common catwalks like the metallic ones, usually have roofs, and use the ramps to overcome the unevenness.

In these works, the load level is much lower when compared to the road and rail bridges, which allows the construction of more economical, slender and flexible structures. However, safety and safety issues need to be taken into account. comfort for pedestrian movement [17].

According to [1], it is important to take into account in any dimensioning the permanent weight of the component. This load, in the case of catwalks, is established by the weight itself, the components that make up the structure and other expected overloads, such as: concrete slab, steel structures, paving, railing, signs, among others.

According to [18] it is necessary to take into account the moving loads to be used on the catwalks as the evenly distributed loads placed on the floor between the railings in the most unfavorable position, not taking into account the vertical impact coefficient. The static value of the evenly diffused moving load shall be adopted at $5.0 \mathrm{kN} / \mathrm{m}^{2}$.

To minimize or eliminate any conflicts, [18] mentions that a $100 \mathrm{kN}$ point horizontal load, employed on the most disadvantageous target of the structure towards the traffic under the catwalk, must be estimated. Superstructure connections and walkway pillars must be examined for this exceptional action. The consideration does not extinguish the assumption of partial or total collapse of the structure due to the magnitude of a possible collision. 
If walkways are narrow, lightweight, sensitive to wind and the dynamic action of pedestrians, they are recognized as special walkways, and should, if they are steel, mixed, suspension or cablestayed structures, be certified for their overall stability and investigation of the various elements. through dynamic models and fatigue investigation.

As [4] mentions that pedestrian circulation can be horizontal and vertical. Vertical circulation can be affected by stairs, ramps or electromechanical equipment and is assessed as accessible when it allows at least two ways of vertical displacement.

Sizing a walkway will initially need to be based on the peak demand value, such as 3,500 pedestrians in 1.5 hours. From this data, the number of pedestrians per minute is calculated:

$$
\mathrm{n}^{\mathrm{o}} \text { users } / \mathrm{min}=\frac{3.500}{1,5^{*} 60 \mathrm{~min}}=39 \text { pedestrians } / \mathrm{min} \text { (Eq. 1) }
$$

Working with 40 pedestrians entering the walkway per minute, the desired level of service should be chosen to meet the peak demand period. The option will have a significant influence on the subsequent sizing steps.

After examining the different levels of service and their distinctions, it can be scaled to a level of service $C$ at its peak hours, considering a space for each pedestrian equal to $2.5 \mathrm{~m} 2$. By achieving these values, it is possible to determine the required footbridge area to accommodate new pedestrians:

$$
\text { Area }=40 * 2,5=100 \mathrm{~m}^{2} / \min \quad \text { (Eq. 2) }
$$

Thus, in order to reach the required width in order to withstand peak hour demand with maintenance of the service situation never below level $\mathrm{C}$, knowledge of the average pedestrian speed is indispensable. Based on the Highway Capacity Manual, it can be seen that for a population (which will make use of the walkway) composed of a maximum of $20 \%$ of people over the age of 65, an average value for speed can be considered. Developed equal to $1.2 \mathrm{~m} / \mathrm{s}$. You can proceed with calculating a user's average speed:

$$
\text { Vaverage }=1,2 * 60=72 \mathrm{~m} / \mathrm{min} \quad \text { (Eq. } 3 \text { ) }
$$

From this data, together with the previously calculated required area per minute, an initial estimate of the required width is possible:

$$
L=\frac{100}{72}=1,39 m \quad(\text { Eq. } 4)
$$

However, if the maximum demand is expected to occur in both directions at peak hours, the width should be doubled, resulting in:

$$
L=2 * 1,39=2,78 m \quad(\text { Eq. } 5)
$$

Paying attention to the suggestion of pedestrians' proximity to the catwalk ends - an additional $50 \mathrm{~cm}$ at both ends is indicated for pedestrians to feel comfortable about the height - the final width equal to:

$$
\text { Lfinal }=0,5+2,78+0,5=3,78 m \quad \text { (Eq. 7) }
$$

Therefore, the minimum width required to meet peak hour demand conditions of 3,500 pedestrians in 1.5 hours and offering a service level greater than or equal to $\mathrm{C}$ is equal to 3.78 meters.

After evaluating all previous calculations, a width of 4.00 meters is adopted. This figure follows the action planned for a $20-$ year horizon, respects the desired level of service and allows stability and slimness to the structure to be achieved due to the existence of relatively large spans, estimated in principle at approximately 80 meters.

For simplicity, it is considered that disabled traffic will not significantly change the flow at peak time. This consideration is reasonable since sizing predicts a higher percentage of older people than expected, given the composition by age of expected demand.

\section{RESULTS AND DISCUSSIONS}

Due to the occurrence of several factors in construction, the study of pathologies in buildings has reached remarkable levels. Until recently it was thought that concrete structures would last forever. For a structure to achieve a satisfactory service life, it must have regular monitoring and maintenance.

When so much scientific knowledge was not yet available, the constructions were executed with very high dimension, thus causing works resistant to certain degrees of considerable pathologies without impairing their integrity.

However, nowadays, the advent of technologies has enabled improvements in both calculations and materials knowledge, works are built with more slenderness, more precisely and therefore require more care.

According to [19], the area of engineering that deals with pathologies is understood as the part of engineering that studies the systems, mechanisms, causes and origins of defects in civil works, i.e., it is the study of the parts that make up the diagnosis of the problem.

The structural pathologies found in bridges and walkways vary in intensity and incidence, often generating high cost for their restoration. In this respect there may be compromised aesthetics and sometimes reduced strength, and some may generate the best solution such as partial or total demolition of the structure.

Detailed analysis of the problem, identification and description of causes, forms of manifestation, mechanisms of occurrence, prophylaxis and structural maintenance are guidelines considered in the study of structural pathologies. The main foundation of the pathology of constructions is "to evaluate a structure that in a given period of its life presented inadequate performance, since the framework presented by it does not necessarily characterize condemnation" [20].

After considering the items in the previous paragraph, the professional will be able to diagnose cases correctly, possibly determining the usual therapeutic measures.

According to [19], it is necessary to study the correction and solution of these pathological problems. For the correct choice and application of therapy, a detailed study that presents the true diagnosis of the origin of the pathology is important.

The choice of either therapy is almost always related to economic or technical factors when a therapy cannot be used in a particular setting or is difficult to perform. When the structure does not have a pathological condition, a program of interventions to extend the structural life should be implemented. In other words, it is a periodic maintenance program.

The nature of concrete becomes unstable over time, due to its physical and chemical characteristics altered due to its 
components and their responses to the impositions made by the environment where the structure performs its functions. Concerns about the performance of a building often focus only on its mechanical strength, suppressing one of the key factors that is durability [21].

According to [22] most of the technical standards regarding concrete in the most varied regions of the world only concern themselves with the issue of mechanical strength without paying due attention to environmental actions, which directly influence durability, as well as other factors such as minimum concrete strength and maximum water / cement ratio (a / c).

In Brazil, the penultimate version of NBR-6118/03 did not highlight the issue of environmental aggressiveness, minimum cement consumption, maximum water / cement ratio, and being condescending with small coverings. These items are directly linked to the durability of reinforced concrete structures.

The main factors that cause effects on reinforced concrete influencing its behavior are: quality of materials; water / cement ratio; environment; actions and quality in the construction process.

Engineering quality must be objective and not subjective, and the quality of a given product should be verified by adjusting it to the relevant standards. The water / cement ratio refers to the ratio between the amount of cement and water used to form the concrete. The amount of water used to promote the hydration reactions of cement compounds and give workability to the mass will indicate characteristics such as density, compactness, permeability, capillarity and the cracking itself, regardless of mechanical strength.

The excessive use of water causes voids and capillaries in the concrete, thus facilitating the transport of harmful fluids from the environment to the interior of the part, causing the carbonation of the concrete and corrosion of the reinforcement.

The environment affects the concrete through the release of gases and liquids that contain some type of aggressive chemical agent, these are introduced concrete by porosity and capillary network. As a result of industrialization, atmospheric aggressiveness has greatly increased, imposing a regime of behavioral changes and material variations, thus resulting in the effects of early corrosion and accelerated carbonation [21].

Unforeseen structural design overloads can cause many cracks, eventually collapsing. Such overloads may have been considered in the structural design, in which case the failure results from the execution of the part or the use of it [23].

The construction process can be divided into three parts: conception or planning, execution and maintenance. The three phases are subject to failure occurrences [22].

Understanding the pathological causes is essential to determine the correct treatment, so it is necessary to ensure that after the procedure of restoration of the building no new pathologies will occur. According to Souza; [22] The causes of structural deterioration can be divided into two major groups, intrinsic and extrinsic causes. Intrinsic causes are the causes of deterioration inherent in the structure itself. They come from the materials and components of the structure.

These causes are generated by human failures in the execution or use phase and by external natural agents such as chemical attacks and even accidents. Already the extrinsic causes, are those that are independent of the structure itself, as well as its composition or failures arising from the implementation. They can be understood as factors that attack structures "from the outside" in the process of conception, execution or its useful life.
Table 4: Intrinsic causes of pathologies in reinforced concrete structures.

\begin{tabular}{|c|c|}
\hline \multicolumn{2}{|c|}{ Human failures during construction } \\
\hline $\begin{array}{c}\text { Concrete } \\
\text { deficiencies }\end{array}$ & $\begin{array}{l}\text { Transport, release, concreting joints, } \\
\text { thickening, curing. }\end{array}$ \\
\hline \multicolumn{2}{|r|}{ Inadequate shoring and forms } \\
\hline $\begin{array}{l}\text { Armor } \\
\text { deficiencies }\end{array}$ & $\begin{array}{l}\text { Misinterpretation of projects } \\
\text { Armor Insufficiency } \\
\text { Bad positioning of the reinforcement } \\
\text { Insufficient concrete cover } \\
\text { Improper bar bending } \\
\text { Anchor deficiencies } \\
\text { Deficiencies in amendments } \\
\text { Misuse of Anticorrosive }\end{array}$ \\
\hline $\begin{array}{l}\text { Misuse of } \\
\text { building } \\
\text { materials }\end{array}$ & $\begin{array}{c}\text { Fck less than specified } \\
\text { Steel other than specified } \\
\text { Soil with different characteristics } \\
\text { Use of reactive aggregate } \\
\text { Inappropriate use of additives } \\
\text { Inadequate dosing of concrete }\end{array}$ \\
\hline \multicolumn{2}{|r|}{ No quality control } \\
\hline \multicolumn{2}{|c|}{ Human failures during use (no maintenance) } \\
\hline \multirow{2}{*}{\multicolumn{2}{|c|}{$\begin{array}{c}\text { Natural causes } \\
\text { Causes proper to the porous structure of concrete }\end{array}$}} \\
\hline & \\
\hline Chemical causes & $\begin{array}{l}\text { Internal reactions to concrete, } \\
\text { expandability of certain cement } \\
\text { constituents, presence of chlorides, } \\
\text { presence of acids and salts, presence of } \\
\text { carbon dioxide, presence of water, } \\
\text { increase of internal temperature of } \\
\text { concrete. }\end{array}$ \\
\hline Physical causes & $\begin{array}{l}\text { Temperature variation, heat stroke, wind, } \\
\text { water }\end{array}$ \\
\hline \multicolumn{2}{|r|}{ Biological causes } \\
\hline
\end{tabular}

Table 5: Extrinsic causes of pathologies in reinforced concrete structures.

\begin{tabular}{|c|c|}
\hline $\begin{array}{c}\text { Human } \\
\text { failures during } \\
\text { the project }\end{array}$ & $\begin{array}{c}\text { Inadequate structure modeling, poor load } \\
\text { evaluation, incorrect or insufficient } \\
\text { detailing, environmental inadequacy, } \\
\text { incorrect soil-structure interaction, } \\
\text { incorrect consideration of expansion joints. }\end{array}$ \\
\hline $\begin{array}{c}\text { Human } \\
\text { failures during } \\
\text { use }\end{array}$ & $\begin{array}{c}\text { Exaggerated Overloads } \\
\text { Change in the conditions of the foundation } \\
\text { ground. }\end{array}$ \\
\hline $\begin{array}{c}\text { Mechanical } \\
\text { actions }\end{array}$ & $\begin{array}{c}\text { Vehicle crashes, foundation failure, } \\
\text { accidents (unpredictable actions). }\end{array}$ \\
\hline $\begin{array}{c}\text { Physical } \\
\text { actions }\end{array}$ & $\begin{array}{c}\text { Temperature variation, heat stroke, water } \\
\text { performance. }\end{array}$ \\
\hline \multicolumn{2}{c}{ Chemical actions } \\
\hline \multicolumn{2}{c}{ Biological actions } \\
\hline
\end{tabular}

\section{CONCLUSION}

The design of a catwalk, no matter how small, has surprising implications that can have very positive or tremendously negative impacts on users, the media, society and the city as a whole. A walkway can reduce the movement of passers-by in the 
other people traffic options and provide them with a faster or shorter course.

The demographic explosion in many countries calls for caution about many urban traffic variables that civil engineering professionals need to be prepared to avoid pandemonium and disruption in transportation strategies and logistics. Therefore, it is essential that the professional is aware of the importance of ordering and fluency of traffic, so as to make it as continuous and safe as possible in facing the progressive demands for accessibility, fluency and speed in the busy life of large cities.

Often, in order to build a masterpiece and make its name prominent among other professionals in the field of construction, the engineer or designer neglects a serious and detailed research of the surroundings, and also not giving due value to the study of Current intersections.

The design of a metal frame or reinforced concrete work requires dimensional refinement, without neglecting to comply with multiple safety factors, avoiding disasters, accidents or misfortunes.

It has been found that it is important to consider the permanent load of the element.

In the case of catwalks, the load must be established in addition to its own weight, by variables that are part of the physical framework itself, other fixed overloads, such as: concrete slab, steel structures, paving, railing, signs, among others. . As for pathologies, it was concluded that the best option to prevent pathological conditions is prevention. Prevention is generated not only by a project or execution within the quality parameters, but mainly by a structural maintenance program. These programs play an important role in any structure, facilitating the verification of structural deterioration states and favoring the reduction of treatment costs.

\section{REFERENCES}

[1] Franco, Y.V. Análise de uma modelagem para passarelas de pedestres sobre rodovias. Departamento Acadêmico de Construção Civil, Universidade Tecnológica Federal do Paraná-UTFPR. Pato Branco, 2015.

[2] Gil, A.C. Métodos e técnicas de pesquisa social. 5.ed. São Paulo: Atlas, 2007.

[3] Fédération Internationale du Betón (FIB). Guidelines for the design of footbridges. Lausanne, Suíça, 2005.

[4] Associação Brasileira de Normas Técnicas. NBR 9050: Acessibilidade a edificações, mobiliário, espaços e equipamentos urbanos. 3 ed. Rio de Janeiro, 2015.

[5] Associação Brasileira de Normas Técnicas. NBR 7188: Carga móvel rodoviária e de pedestres em pontes, viadutos, passarelas e outras estruturas. 2.ed. Rio de Janeiro, 2013.

[6] Rosenblum, A. Pontes em estruturas segmentadas prémoldadas protendidas: análise e contribuições ao gerenciamento do processo construtivo. Dissertação (Mestrado) - Curso de Engenharia Civil, Universidade do Estado do Rio de Janeiro, Rio de Janeiro, 2009.

[7] Leonhardt, F. Construções de concreto: Princípios básicos da construção de pontes de concreto. 1.ed. Rio de Janeiro: Interciência, 1979.
[8] Fialho, A.P.F. Passarelas urbanas em estrutura de aço. Ouro Preto, 2004.

[9] Pfeil, W. Concreto armado: dimensionamento. 2.ed. Rio de Janeiro: Livros Técnicos e Científicos, 1983.

[10] Quadros, B.C. Passarela em arco com tabuleiro inferior: Proposta de projeto para o campus central da Universidade Federal do Rio Grande do Sul. Porto Alegre, 2012.

[11] Pimenta, D.S. Produção de concreto convencional com a utilização de pó de brita. TCC (Graduação) - Curso de Engenharia Civil, Universidade Federal da Paraíba, João Pessoa, 2012.

[12] Associação Brasileira de Normas Técnicas. NBR 12655: Concreto - Preparo, controle e recebimento. Rio de Janeiro, 1996.

[13] Associação Brasileira de Pedestres (ABRASPE). Passarelas e passagens subterrâneas: propostas. Joinville, 2000.

[14] BRASIL. Departamento Nacional de Estradas de Rodagem. Diretoria de Desenvolvimento Tecnológico. Divisão de Capacitação Tecnológica. Manual de projeto de obras de arte especiais. Rio de Janeiro, 1996.

[15] Departamento Nacional de Infraestrutura De Transportes, 2010.

[16] Departamento Nacional de Infraestrutura De Transportes, 2015.

[17] Costa, D.C. Análise do comportamento dinâmico de uma ponte pedonal. 2012. 93 f. Dissertação (Mestrado). Curso de Engenharia Civil, Instituto Superior de Engenharia de Lisboa, Lisboa, 2012.

[18] Associação Brasileira de Normas Técnicas. Carga móvel rodoviária e de pedestres em pontes, viadutos, passarelas e outras estruturas. 2013.

[19] Perdrix, C.A. Manual para Diagnóstico de Obras Deterioradas por Corrosão de Armaduras. Trad. Carmona, Antonio; Helene, Paulo R. São Paulo: Pini, 1992.

[20] Soriano, J. Patologias das construções. Itatiba, Universidade São Francisco (USF), agosto 2004. Notas de aula.

[21] Silva, P.F.A. Durabilidade das estruturas de concreto aparente em atmosfera urbana. São Paulo: Pini, 1995.

[22] Souza, V.C.M.; Ripper, T. Patologia, recuperação e reforço de estruturas de concreto. 1.ed. São Paulo: Pini, 1998.

[23] Thomaz, E. Trincas em edifícios. 1.ed. São Paulo: Pini, 1989. 